\title{
Water quality assessment of an urban stream in Lages, Brazil, through analysis of water physicochemical properties and study of benthic macroinvertebrate communities
}

\author{
Monitoramento da qualidade da água de um córrego urbano em Lages- \\ SC, através da análise de macroinvertebrados bentônicos e por meio de \\ parâmetros físico-químicos
}

\author{
Josiane Teresinha Cardoso' \\ Sandy Bernardi Falcadi Tedesco Girotto" \\ Flávia Arcari da Silvall! \\ Viviane Aparecida Spinelli Schein ${ }^{\text {IV }}$ \\ Daiana Petry Leitev
}

\begin{abstract}
Urban growth causes environmental problems such as water contamination which, in turn, affects aquatic organisms and human populations. This work presents a study of an urban stream in Lages, SC, Brazil, hit by continued sewage discharge along part of its course. Through analysis of physicochemical and biological parameters, the water was classified according to the CONAMA Resolution 357/05 and the BMWP' index. Samples were collected 5 times over one year at 5 sites: 2 sites upstream the area of sewage discharge, 2 sites in the area, and 1 site downstream the area. Dissolved oxygen, temperature, $\mathrm{pH}$, phosphate, colour, and turbidity were the analysed physicochemical parameters. Benthic mocroinvertebrates were utilized for the biologic analyses. The sites upstream the area of sewage discharge presented the highest BMWP' and diversity indices, highest dissolved oxigen rates, and the lowest concentration of total phosphorus. Water at these sites was ranked class 1 . The other sites, in and downstream the area of sewage discharge, presented the lowest dissolved oxygen rates, high total phosphorus and turbidity values, and the lowest diversity and uniformity values. Water at these sites was ranked class 4 (polluted). Data analysis is in agreement with the degree of pollution observed along the stream, which undergoes anthropogenic impacts from source to canalization.
\end{abstract}

Keywords: Bioindicators; Physicochemical analysis; BMWP' index

\footnotetext{
I PhD in Entomology, Department of Environmental and Sanitary Engineering, State University of Santa Catarina CAV, Lages, SC, Brazil. josiane.cardoso@udesc.br

"Master's degree in Environmental Sciences, Department of Environmental and Sanitary Engineering, State University of Santa Catarina - CAV, Lages, SC, Brazil. sandy_girotto@hotmail.com

III Master's student in Environmental Sciences, Department of Environmental and Sanitary Engineering, State University of Santa Catarina - CAV, Lages, SC, Brazil. flarcari@hotmail.com

IV PhD in Analytical Chemistry, Department of Environmental and Sanitary Engineering, State University of Santa Catarina - CAV, Lages, SC, Brazil. viviane.schein@udesc.br

$\checkmark$ Master's degree in Electrical Engineering, Department of Environmental and Sanitary Engineering, State University of Santa Catarina - CAV, Lages, SC, Brazil. daiana.petry@udesc.br
} 


\section{Resumo}

O crescimento das cidades traz problemas ambientais, como despejos em corpos hídricos, cuja contaminação traz consequências aos organismos aquáticos e às populações humanas. O objetivo do trabalho foi estudar um córrego urbano em Lages, SC, que sofre despejo de esgoto. Analisou-se parâmetros físico-químicos e biológicos da água e realizou-se sua classificação de acordo com a Resolução 357/05/CONAMA e o índice biótico BMWP'. Separou-se o córrego em cinco áreas: duas a montante dos despejos, dois na área e um a jusante, com cinco coletas realizadas em um ano. $\mathrm{Na}$ avaliação físico-química mediu-se os parâmetros $\mathrm{OD}$, temperatura, $\mathrm{pH}$, fosfato, cor e turbidez. $\mathrm{Na}$ análise biológica utilizou-se macroinvertebrados bentônicos. Os resultados indicam os pontos a montante com os menores valores de fósforo, maiores valores do índice BMWP', taxa de OD e dos índices de diversidade e águas Classe I. Os pontos seguintes apresentaram águas de qualidade diminuindo de duvidosa para poluída, menores taxas de OD, valores elevados de fósforo e turbidez, classificação como Classe IV e menores valores de diversidade e uniformidade. A análise mostrou coerência entre os resultados encontrados e o grau de poluição do Córrego e permitiram concluir que ele está sob pressão antrópica, desde sua nascente, até sua canalização.

Palavras-chave: Bioindicadores; Análise físico-química; Índice BMWP 


\section{Introduction}

Water is fundamental for maintenance of life and the well-being of species but the environment has been severely impacted by population and industry unplanned growth. In Brazil, water quality problems are primarily caused by the discharge of a great amount of non-treated domestic sewage into rivers and streams (CUNHA et al., 2005). As a matter of fact, only $44 \%$ of brazilian houses are served by wastewater systems (IBGE, 2008). Contaminated water, in addition to causing public health problems, also affects aquatic organisms that depend on clean environments to survive. Water quality monitoring based on the identification and quantification of these organisms is very important for prevention and control of future wastewater discharges.

One of the directives of the National Policy on Water Resources (Law 9.433/97) is the systematic management of the quantity and quality of water resources. Resolution 357/05 of the National Environment Council (CONAMA) is the legal instrument whichs sets out a classification of bodies of water based on their contamination status (BRASIL, 1997), and determines the conditions and methods for discharging domestic and industrial effluents. Establishing water quality standards according to accepted practices (BRASIL, 2005) is essential for environmental control and pollution prevention.

Water-related environmental problems require the development of quick and reliable evaluation methods (BUSS et al., 2003). For example, the monitoring of water physicochemical and biological parameters is a practical approach that helps determine the degree of water contamination resulting from anthropogenic factors (ORTIZ et al., 2008).

Several physicochemical parameters are proposed in Resolution 357/05 as criteria for classification of a body of water: dissolved oxygen, $\mathrm{pH}$, water temperature, biochemical oxygen demand, turbidity, colour, phosphorus concentration, nitrogen concentration, etc. Although the measurement of these variables provides knowledge about the type and causes of anthropogenic contaminations, the negative effects on 
the ecosystem biota can only be assessed through the study of biological indicators. When both analyses are combined, we have a complete cause-effect evaluation that reveals not only water quality conditions, but also the real impacts of several xenobiotics on the biota during occasional or chronic expositions (BUSS et al., 2003; GOULART and CALLISTO, 2003; KONIG et al., 2008).

Freshwater benthic macroinvertebrates are a group of organisms intensely utilized in biological monitoring of aquatic ecosystems. They are found on the bottom of bodies of water during part of their life cycle and are associated to a number of organic (leaf litter, aquatic macrophytes) and inorganic (gravel, sand, stones) substrates (ROSENBERG and RESH, 1993).

Distribution and diversity of macroinvertebrates are directly influenced by factors such as type of substrate, ecosystem morphology, quantity and type of organic detritus, aquatic vegetation, and extension of riparian vegetation. On the other hand, they are indirectly affected by alterations in the concentration of nutrients and changes in the primary productivity (GOULART and CALLISTO, 2003). Benthic organisms can be sensitive or tolerant to environmental adversities.

Sensitive macroinvertebrates are mostly water insects (Ephemeroptera, Trichoptera, Plecoptera) which need high concentrations of dissolved oxygen as well as diversified habitats and microhabitats to survive. Tolerant species are water insects, molluscs, bivalves, some Families of Diptera, and representants of the Orders Heteroptera, Odonata, and Coleoptera. They are essentially detritivore, feeding on the organic matter deposited on the sediment, and capable of bearing anoxia (GOULART and CALLISTO, 2003).

Research on water quality has been done with the use of biologic indices that are calculated for communities of macroinvertebrates. The BMWP (Biological Monitoring Working Party) index is the sum of "tolerance values" assigned to macroinvertebrate groups according to their sensitivity to organic pollutants (BISPO et al., 2006). The BMWP' index is an adaptation made by Loyola (2000) for rivers in the state of Paraná and utilized by the Paraná Environmental Institute in the 
biomonitoring of aquatic systems (GONÇALVES, 2007). It is a qualitative index that takes into account only the presence or absence of Families of benthic macroinvertebrates, which are organized into 7 groups from least to most tolerant to organic pollution, and a value from 10 to 1 is assigned to each Family. More sensitive organisms receive higher scores, whereas less sensitive (more tolerant) organisms receive lower scores. The index is useful for comparing sites with different degrees of integrity (SILVEIRA, 2004).

Application of the BMWP' index is inexpensive, quick, relatively easy, and quite convenient in the management of water basins. Neither specific identification nor a high degree of taxonomy knowledge are required since the organisms are usually identified only to Family level (LOYOLA, 2000; SILVEIRA, 2004).

Considering the scarcity of research on the quality of water of streams in the municipality of Lages, this work sets out to investigate an urban stream belonging to the Carahá River catchment area, characterizing its physicochemical properties as well as identifying, quantifying, and analysing its communities of benthic macroinvertebrates in order to assess the extent of observed anthropogenic impacts.

\section{Materials and methods}

\subsection{Study area}

The municipality of Lages $\left(27^{\circ} 48^{\prime} \mathrm{S} ; 50^{\circ} 20^{\prime} \mathrm{W}\right)$ is located in the uplands to the south of the state of Santa Catarina, known as "Planalto Serrano", at an altitude of 916 $\mathrm{m}$ above sea level, with subtropical climate and average yearly temperature of $14.3^{\circ} \mathrm{C}$ (Figure 1).

The investigated stream is a tributary of the Carahá River and part of the great Canoas River basin. It runs across an urban area (district of Vila Comboni, estimated population of 540 inhabitants) located within the boundaries of a state experimental station for agricultural and livestock research (EPAGRI). The most part of the stream drainage basin is also within the experimental station and is impacted by the disposal 
of effluents and other residues resulting from human and animal activities. Its headwaters are located in a preserved area (Figure 2).

Figure 1 - Municipality of Lages, Santa Catarina, Brazil

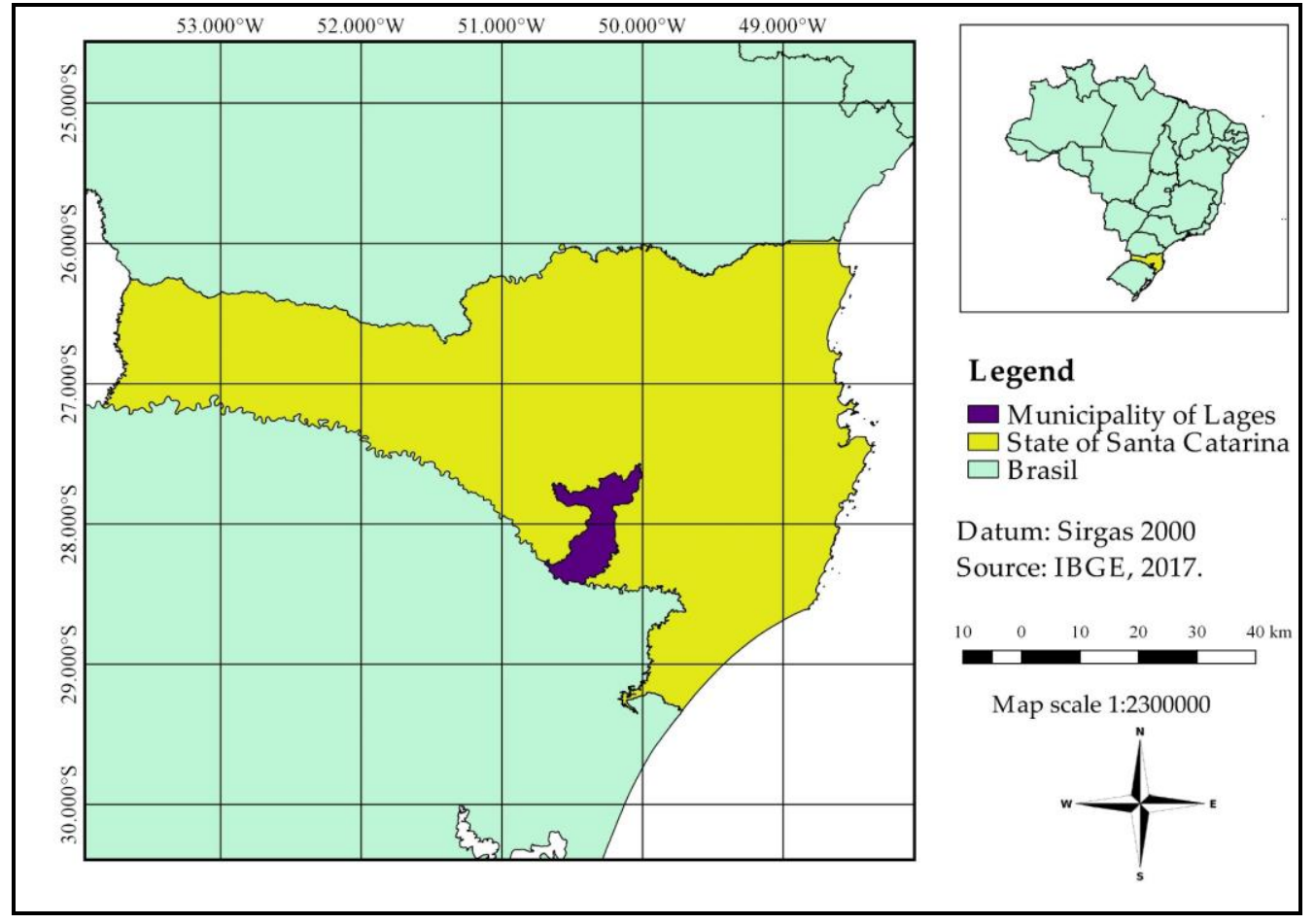

Figure 2 - Study area: experimental station, sample collection sites (red marks), and district of Vila Comboni. Lages, Brazil

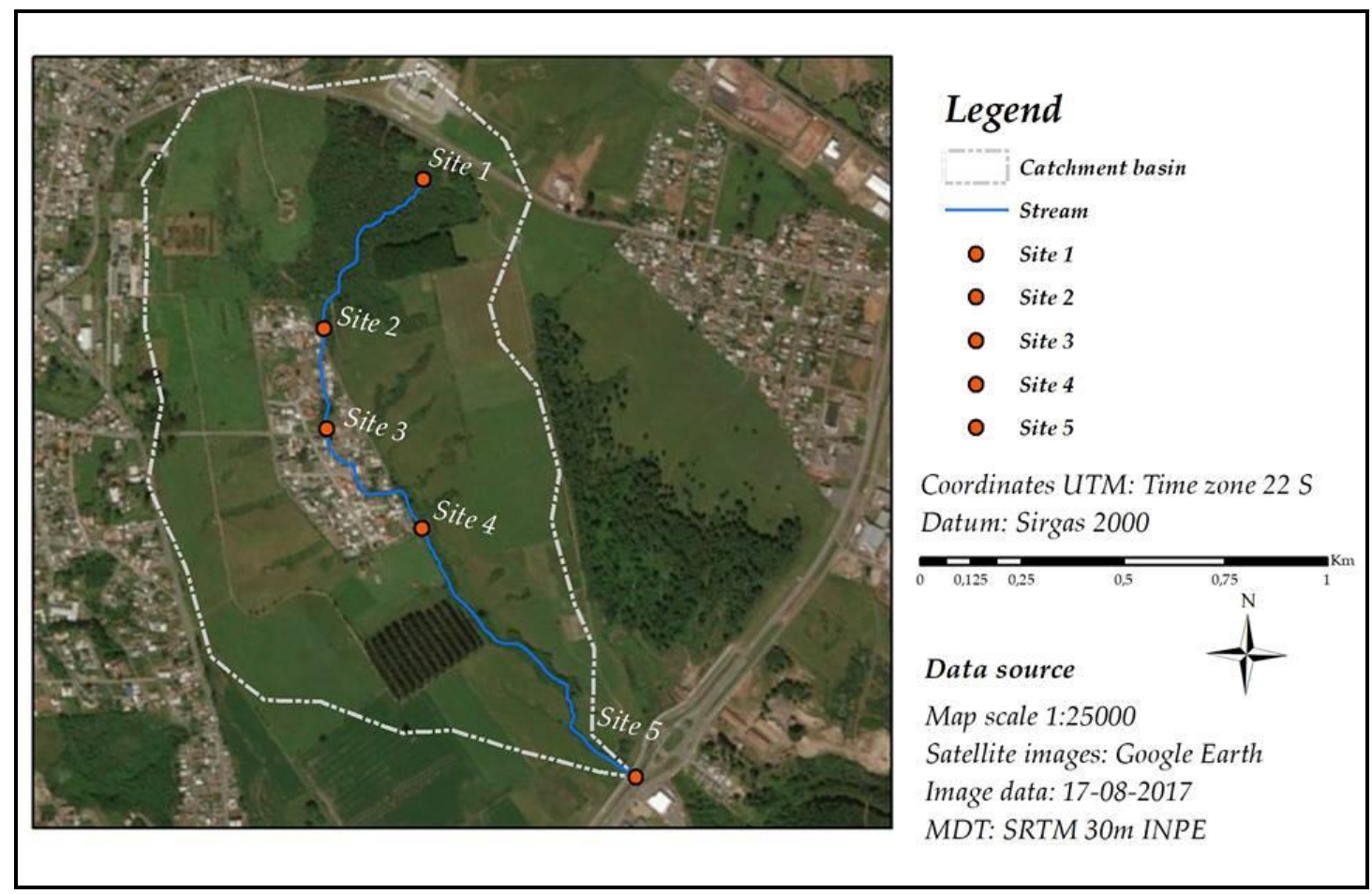


Samples were collected every two months, from August 2012 to April 2013, at 5 sites along the stream: site $1\left(27.8041^{\circ} \mathrm{S} ; 50.3358^{\circ} \mathrm{W}\right)$ at the source; site $2\left(27.8046^{\circ} \mathrm{S}\right.$; $\left.50.3318^{\circ} \mathrm{W}\right)$ at the south boundary of the district; site $3\left(27.8036^{\circ} \mathrm{S} ; 50.3292^{\circ} \mathrm{W}\right)$ in the district; site $4\left(27.8011^{\circ} \mathrm{S} ; 50.3290^{\circ} \mathrm{W}\right)$ at the north boundary of the district; and site 5 $\left(27.7957^{\circ} \mathrm{S} ; 50.3267^{\circ} \mathrm{W}\right)$ further downstream, at the north boundary of the experimental station (Figure 2).

Site 1 (in the headwaters) is surrounded by native riparian vegetation and a pine plantation (Pinus). Site 2, previously an area of experimental livestock farming, is characterized by regenerated native vegetation. At site 3 , in the district, vegetation is scarce, with a few exotic and native plants growing along the streamside. Site 4 is surrounded by a small portion of native and exotic riparian vegetation. At site 5 , an area of active experimental livestock farming and no riparian vegetation, cattle can easily reach the stream banks.

\subsection{Physicochemical analysis}

Water samples were collected with previously identified $750 \mathrm{~mL}$ polyethylene flasks and kept in cooling boxes prior to being taken to the laboratory on the university campus.

Dissolved oxygen and temperature field measurements were made with a portable Luton D05519 oxygen meter. At the laboratory, pH measurements were made with a TECNOPON workbench $\mathrm{pH}$ meter. A Spectroquant ${ }^{\circledR}$ NOVA 60A photometer was utilized for the determination of colour by the platinum-cobalt method, phosphate by the molybdenum blue assay, and turbidity by the colorimetric method at $550 \mathrm{~nm}$.

The data were evaluated by the Principal Component Analysis (PCA) and Linear Discriminant Analysis (LDA) with the utilization of a statistical software (Minitab). 


\subsection{Benthic macroinvertebrate analysis}

A modified version of the protocol proposed by SILVEIRA et al. (2000) for the collection and preparation of samples was adopted: a net sampler (Surber, $250 \mathrm{~mm}$ ) was placed against the current and the sorrounding substrate was wiped into the net for 1 minute. Three samples were taken from each site (substrates of the left bank, right bank, and streambed), put into plastic bags, and kept in previously identified containers.

In the laboratory, the samples were passed through sieves ( $1 \mathrm{~mm}$ and $250 \mu \mathrm{m})$ and washed in running water. After manual separation from organic residues and detritus (MOZETO et al., 2006), the organisms were preserved in $70 \%$ ethanol. Later, with the use of identification guides, they were identified to Family level in a stereomicroscope.

\subsection{BMWP' and EPT indices}

After identification of all the taxa contained in the samples, their "tolerance values" were calculated to yield the BMWP' index for each site. Water quality classification is shown in Table 1.

Table 1 - Water quality classification based on BMWP' indices according to ALBATERCEDOR and SANCHEZ-ÓRTEGA (1988), modified for the Paraná Department of Environment and Water Resources, 2016

\begin{tabular}{cccc}
\hline Class & Quality & BMWP' value & Meaning \\
\hline I & Excellent & $>150$ & Very clean waters (pristine waters) \\
\hline II & Good & $121-150$ & $\begin{array}{c}\text { Clean waters, not polluted, or not } \\
\text { perceptibly altered }\end{array}$ \\
\hline III & Acceptable & $101-120$ & $\begin{array}{c}\text { Slightly polluted waters, or somewhat } \\
\text { altered }\end{array}$ \\
\hline IV & Questionable & $100-61$ & Waters with apparent moderate \\
pollution
\end{tabular}


Continuation...

\begin{tabular}{cccc}
\hline $\mathrm{VI}$ & Very polluted & $35-16$ & Very contaminated waters \\
\hline $\mathrm{VII}$ & $\begin{array}{l}\text { Strongly } \\
\text { polluted }\end{array}$ & $<16$ & Strongly contaminated waters \\
\hline
\end{tabular}

Additionally, the EPT index was calculated. It is a measure of the relative abundance (percentage) of Ephemeroptera, Plecoptera, and Thricoptera present in a sample. The results are then compared to given values. Higher percentages indicate better water quality (Table 2 - GONÇALVES, 2007).

Table 2 - EPT value ranges and corresponding quality grades

\begin{tabular}{lc}
\hline Porcent of EPT & Quality \\
\hline $75 \%-100 \%$ & Very good \\
$50 \%-74 \%$ & Good \\
$25 \%-49 \%$ & Average \\
$0 \%-24 \%$ & Poor \\
\hline
\end{tabular}

\subsection{Diversity and similarity indices}

Measurements of taxa diversity and taxa similarity are especially useful to compare samples over time and along stream segments (RORIG, 2013).

The Shannon diversity index $(H)$ is found in a number of studies, including those related to benthic macroinvertebrates (COPATTI et al., 2010; BARBOLA et al., 2011). It is a measure of the uncertainty in predicting to which species a chosen individual belongs. It is zero if only one species occurs in a sample, and maximum when all species are represented by the same number of individuals. The Pielou diversity index (E) describes how the individuals are distributed over different species. It is calculated from the results obtained for the Shannon index, and varies from 0 to 1 (RORIG, 2013).

The Jaccard similarity index is based on a qualitative comparison of taxa in samples from different locations. It is calculated by considering the presence or 
absence of species in the samples and varies from 0 (communities totally different in terms of composition of species) to 1 (communities totally similar in terms of composition of species) (ZANZINI, 2005).

\section{Results and discussion}

A total of 5 sampling procedures were carried out over the seasons, from August 2012 to April 2013. The data collected in December 2012 were altered due to drought (water shortage presumably caused an increase in the concentration of suspended particles coming from the stream banks). As the stream source dried up, site 1 could not be sampled in that month. Results are shown in Table 3.

Site 1 (in the headwaters; a fenced-off area with more riparian vegetation): mean values were within the limits defined by Resolution 357/05 for class 1 fresh waters: Dissolved oxygen not lower than $6 \mathrm{mg} \cdot \mathrm{L}^{-1}$; turbidity below 40 UNT; pH between 6 and 9; and total phosphorus below $0.1 \mathrm{mg} \cdot \mathrm{L}^{-1}$. Colour mean value was low $(1 \mathrm{~Hz})$ due to reduced organic matter and humic compounds in water. All parameters indicated low contamination from sewage discharge and other pollutants.

Site 2 (south boundary of the district; an open area with riparian vegetation in regeneration process): mean values within specification for class 1 fresh waters. Colour was observed to be higher $(20.25 \mathrm{~Hz})$, indicating a greater amount of organic matter and humic compounds.

Site 3 (in the district; sewage discharge from nearby houses): levels of turbidity (17 UNT), pH (6.63), and colour $(44.5 \mathrm{~Hz})$ indicated a higher amount of suspended particles and organic matter in water. From the values of dissolved oxygen (3.7 mg. $\mathrm{L}^{-1}$ ) and total phosphorus $\left(0.4 \mathrm{mg} \cdot \mathrm{L}^{-1}\right)$, the site was ranked class 4 by the CONAMA specification.

Site 4 (north boundary of the district; heavy sewage discharge): lower level of dissolved oxygen (2.5 mg. $\left.\mathrm{L}^{-1}\right)$ and higher values of colour and total phosphorus indicating more organic matter in water. From the values of dissolved oxygen and total phosphorus, the site was ranked class 4 by the CONAMA specification. 
Site 5 (downstream the district; livestock farming in the nearby area): the value of colour was highest, indicating the greatest amount of organic matter in water. From the values of dissolved oxygen and total phosphorus, the site was ranked class 4 by the CONAMA Resolution.

In the statistical analysis of the physicochemical data, the sites were divided into two significantly distinct groups, according to values of colour and turbidity. Sites 1 and 2 (group 1) were ranked class 1 by Resolution 357/05, whereas sites 3, 4, and 5 (group 2) were ranked class 4 . The statistical treatment showed that only the parameters colour and turbidity made a real contribution to site differentiation. Thus, sites 1 and 2 are cleaner and sites 3, 4, and 5 are more polluted (they have more organic matter and suspended particles in water).

Table 3 - Average physicochemical measurements and quality classification according to the CONAMA Resolution 357/05.

\begin{tabular}{c|c|c|c|c|c|c|c}
\hline \multirow{2}{*}{ Sites } & \multicolumn{6}{|c|}{ Mean value \pm Standard deviation (parameters estimated to within a 95\% confidence } & \multirow{2}{*}{$\begin{array}{c}\text { Quality } \\
\text { interval) }\end{array}$} \\
\cline { 2 - 7 } & $\begin{array}{c}\text { Dissolved } \\
\text { oxygen } \\
\left(\mathrm{mg} . \mathrm{L}^{-1}\right)\end{array}$ & $\begin{array}{c}\text { Temperature } \\
\left({ }^{\circ} \mathrm{C}\right)\end{array}$ & $\begin{array}{c}\text { Turbidity } \\
(\mathrm{UNT})\end{array}$ & Colour (Hz) & $\mathrm{pH}$ & $\begin{array}{c}\text { Total } \\
\text { phosphorus } \\
\left(\mathrm{mg} . \mathrm{L}^{-1}\right)\end{array}$ & classification \\
\hline 1 & $8.1 \pm 0.5$ & $16.5 \pm 5.4$ & $\begin{array}{c}6.8 \pm \\
10.3\end{array}$ & $1.0 \pm 0$ & $\begin{array}{c}6.8 \pm \\
1.2\end{array}$ & $0.09 \pm 0.1$ & Class 1 \\
\hline 2 & $7.1 \pm 1.7$ & $17.7 \pm 6.5$ & $7.2 \pm 7.9$ & $\begin{array}{c}20.2 \pm \\
22.5\end{array}$ & $\begin{array}{c}6.8 \pm \\
1.1\end{array}$ & $0.06 \pm 0.05$ & Class 1 \\
\hline 3 & $3.7 \pm 0.2$ & $16.7 \pm 3.3$ & $\begin{array}{c}17.0 \pm \\
13.2\end{array}$ & $\begin{array}{c}44.5 \pm \\
18.4\end{array}$ & $\begin{array}{c}6.7 \pm \\
0.8\end{array}$ & $0.4 \pm 0.05$ & Class 4 \\
\hline 4 & $2.5 \pm 1.5$ & $18.3 \pm 4.0$ & $\begin{array}{c}16.7 \pm \\
9.6\end{array}$ & $\begin{array}{c}70.8 \pm \\
84.7\end{array}$ & $\begin{array}{c}6.8 \pm \\
0.9\end{array}$ & $0.7 \pm 0.3$ & Class 4 \\
\hline 5 & $4.9 \pm 2.1$ & $16.8 \pm 2.9$ & $\begin{array}{c}14.7 \pm \\
7.4\end{array}$ & $\begin{array}{c}76.8 \pm \\
87.7\end{array}$ & $\begin{array}{c}6.7 \pm \\
0.5\end{array}$ & $0.6 \pm 0.7$ & Class 4 \\
\hline
\end{tabular}

A total of 33.808 individuals were identified in the survey, and divided into 6 classes of invertebrates: Malacostraca, Gastropoda, Bivalvia, Insecta, Olichaeta, and Hirudinida (Table 4). Chironomidae, Oligochaeta, and Hyalellidae were the most abundant taxa, in this order (Chironomidae was the most abundant taxon in 4 of the 5 sites). 
Table 4 - Total benthic macroinvertebrates identified in the surveyed stream.

\begin{tabular}{|c|c|c|c|c|c|c|c|c|}
\hline Class & Order & Family & Site 1 & Site 2 & Site 3 & Site 4 & Site 5 & Total \\
\hline \multirow{3}{*}{ Malacostraca } & Amphipoda & Hyalellidae & 0 & 17 & 3 & 38 & 2.034 & 2.092 \\
\hline & Decapoda & Aeglidae & 32 & 24 & 0 & 0 & 0 & 56 \\
\hline & Isopoda & & 1 & 0 & 4 & 0 & 0 & 5 \\
\hline \multirow{3}{*}{ Gastropoda } & & Hidrobiidae & 0 & 0 & 562 & 95 & 97 & 754 \\
\hline & & Planorbidae & 0 & 2 & 6 & 2 & 3 & 13 \\
\hline & Basommatophora & Ancylidae & 0 & 0 & 291 & 14 & 87 & 392 \\
\hline Bivalvia & & & 0 & 0 & 24 & 5 & 1.785 & 1.814 \\
\hline \multirow{23}{*}{ Insecta } & Coleoptera & Noteridae & 0 & 0 & 1 & 1 & 4 & 6 \\
\hline & & Dytiscidae & 0 & 0 & 2 & 1 & 4 & 7 \\
\hline & & Elmidae & 12 & 6 & 2 & 0 & 2 & 22 \\
\hline & & Hydrophilidae & 1 & 0 & 4 & 1 & 0 & 6 \\
\hline & & Psephenidae & 0 & 0 & 7 & 0 & 0 & 7 \\
\hline & & Staphylinidae & 1 & 0 & 0 & 1 & 0 & 2 \\
\hline & Diptera & Ceratopogonidae & 1 & 0 & 0 & 1 & 0 & 2 \\
\hline & & Chironomidae & 117 & 223 & 9.452 & $\begin{array}{c}11.71 \\
8\end{array}$ & 629 & $\begin{array}{c}22.13 \\
9\end{array}$ \\
\hline & & Culicidae & 19 & 3 & 212 & 118 & 3 & 355 \\
\hline & & Dolichopodidae & 1 & 0 & 0 & 0 & 0 & 1 \\
\hline & & Empididae & 0 & 0 & 2 & 2 & 0 & 4 \\
\hline & & Muscidae & 0 & 0 & 3 & 0 & 0 & 3 \\
\hline & & Tabanidae & 0 & 3 & 0 & 2 & 0 & 5 \\
\hline & & Tipulidae & 12 & 18 & 0 & 12 & 1 & 43 \\
\hline & & Psychodidae & 0 & 0 & 33 & 9 & 0 & 42 \\
\hline & & Syrphidae & 0 & 3 & 5 & 1 & 0 & 9 \\
\hline & Ephemeroptera & Leptophlebiidae & 46 & 1 & 0 & 0 & 0 & 47 \\
\hline & & Leptohyphidae & 43 & 8 & 0 & 0 & 0 & 51 \\
\hline & Heteroptera & Mesoveliidae & 1 & 1 & 0 & 0 & 0 & 2 \\
\hline & & Saldidae & 16 & 3 & 0 & 0 & 0 & 17 \\
\hline & & Veliidae & 1 & 0 & 0 & 0 & 0 & 1 \\
\hline & Lepidoptera & Pyralidae & 0 & 2 & 0 & 0 & 0 & 2 \\
\hline & Odonata & Aeshnidae & 0 & 1 & 0 & 0 & 5 & 6 \\
\hline
\end{tabular}


Continuation...

\begin{tabular}{l|c|c|c|c|c|c|c|c}
\hline & & Coenagrionidae & 1 & 0 & 1 & 1 & 6 & 9 \\
\cline { 2 - 9 } & & Libellulidae & 1 & 0 & 2 & 0 & 3 & 6 \\
\cline { 2 - 10 } & Trichoptera & Calamoceratidae & 2 & 0 & 0 & 0 & 0 & 2 \\
\cline { 2 - 9 } & & Leptoceridae & 16 & 0 & 0 & 0 & 0 & 16 \\
\cline { 2 - 9 } & Plecoptera & Gripopterygidae & 0 & 2 & 0 & 0 & 0 & 2 \\
\cline { 2 - 9 } & & Perlidae & 2 & 1 & 0 & 0 & 0 & 3 \\
\hline Oligochaeta & & & 1 & 11 & 95 & 4.132 & 789 & 5.028 \\
\hline
\end{tabular}

The greatest taxonomic richness was observed in site 1: 23 taxa out of 39 collected. Chironomidae was the most abundant Family $(34.2 \%$ of the total of individuals). By the BMWP' index, site 1 was classified as having acceptable water quality with low pollution levels, being a slightly altered system (Table 5). Terrain characteristics might have caused leaching of organic substances into the stream and the consequent increase in the population of Chironomidae. Although pollutants were detected, the best results of turbidity, colour, and dissolved oxygen, as well as the second-lowest concentration of total phosphorus were observed.

Richness and abundance were greatest at site 1, with the presence of pollutionsensitive Families such as ephemeropterans of the Families Leptophlebiidae and Leptohyphidae; trichopterans of the Families Calamoceratidae, Hydropsychidae, and Leptoceridae; and plecopterans of the Family Perlidae. By the EPT index, site 1 was classified as having average water quality (Table 6). According to GONÇALVES (2007) in a study conducted in a river on the coast of Paraná, this is equivalent to "acceptable/questionable" water quality, by the BMWP' index.

A similar abundance was observed at site 2, but a lower taxonomic richness: 19 taxa in total. Chironomidae was the most abundant Family $167.5 \%$ of the total collected). By the BMWP' index, site 2 was classified as having a questionable water quality, with moderate pollution effects. By Resolution 357/05, however, it was 
considered a class 1 location, with physicochemical characteristics very close to those of site 1. By the EPT index, site 2 was classified as having poor water quality (Table 6), which corresponds to "very/strongly polluted water", by the BMWP' index (GONÇALVES, 2007). The disagreement between the three rankings (Resolution 357/05, BMWP' index, and EPT index) requires more investigation for site 2.

The riparian zone at site 2 (which has previously been an area for pasture) is composed of plants in regeneration process. Leaching of organic matter into the stream might have caused the high abundance of Chironomidae and a decreasing number of sensitive organisms, but this was not detected in the collected sediments.

Table 5 - BMWP' indices and water quality rankings

\begin{tabular}{lccccc}
\hline & Site 1 & Site 2 & Site 3 & Site 4 & Site 5 \\
\hline $\begin{array}{l}\text { BMWP' } \\
\text { score }\end{array}$ & 105 & 88 & 64 & 57 & 58 \\
\hline $\begin{array}{l}\text { Water } \\
\text { quality }\end{array}$ & Acceptable & Questionable & Questionable & Polluted & Polluted \\
\hline
\end{tabular}

Chironomidae was also the most abundant Family ( $82.7 \%$ of total collected) at site 3, followed by Hirudinida and Hidrobiidae. Similarly, by the BMWP' index, site 3 was classified as having questionable water quality, with moderate pollution effects. A noticeable increase in the abundance of resistent organisms (Chironomidae, Oligochaeta, and Hirudinida) was observed, as well as the absence of Trichoptera, Ephemeroptera, and Plecoptera. By the EPT index, the site was classified as having poor water quality (Table 6). Despite the occurrence of raw sewage discharges, part of the organic matter in water may be derived from eroded portions of the stream banks, which have no riparian vegetation.

Site 4 was classified as having contaminated (by the BMWP' index) and poor (by the EPT index) water. Because of the intense sewage discharge, the water quality was worst.

Chironomidae and Oligochaeta were the most abundant taxa: respectively, $72.3 \%$ and $25.5 \%$ of the total collected $(98 \%$ of the total of macroinvertebrates 
collected). Accordingly, from the physicochemical analysis, the concentration of dissolved oxygen was lowest, and total phosphorus was highest.

Site 5 was classified as polluted, with a BMWP' score close to that of site 4. All sewage discharge and other contaminants coming from upstream areas were present. Despite the existence of a small zone of riparian vegetation, no process of water self-cleaning was observed.

Hyalellidae (detritivore-shredder organisms that feed on vascular plant tissues and decaying wood) and Bivalvia (filtering-collector organisms that feed on fine particulate organic mater - MERRIT et al., 2014) were the most abundant Families ( $68 \%$ of the total collected). Presumably, fragmented organic matter from the riparian vegetation that is found on the stream bank has served as food for the population of Hyalellidae, whereas sewage fine particulate organic matter has served as food for the population of Bivalvia and other abundant detritivores such as Oligochaeta and Chironomidae. No specimens of Trichoptera, Ephemeroptera, and Plecoptera was found. Water quality was considered poor $(E P T=0)$.

Table 6 - Percentage of Ephemeroptea, Plecoptera and Trichoptera (EPT) collected in the studied stream. Lages, Brazil

\begin{tabular}{lccccc}
\hline & Site 1 & Site 2 & Site 3 & Site 4 & Site 5 \\
\hline \% EPT & 33.4 & 3.6 & 0 & 0 & 0 \\
\hline Water quality & Average & Poor & Poor & Poor & Poor \\
\hline
\end{tabular}

The Shannon $(H)$ and Pielou $(E)$ indices were calculated in order to understand pollution effects on the diversity of taxa at each site (Table 7). According to FERRERO (2007), the Shannon index gives information about community stability: as pollution increases, the most sensitive organisms begin to disapear, competition for food and space decrease, more tolerant organisms become abundant, and stability diminishes. In general, low values of $\mathrm{H}$ and $\mathrm{E}$ indicate many individuals distributed over few taxa, 
while high values of $\mathrm{H}$ and $\mathrm{E}$ indicate fewer individuals and greater diversity of species (RORIG, 2013).

Table 7 - Taxa diversity indices of benthic macroinvertebrates collected in the studied stream

\begin{tabular}{llllll}
\hline & Site 1 & Site 2 & Site 3 & Site 4 & Site 5 \\
\hline Shannon index $(\mathrm{H})$ & 2.109 & 1.401 & 0.733 & 0.707 & 1.519 \\
\hline Pielou index $(\mathrm{E})$ & 0.673 & 0.468 & 0.241 & 0.236 & 0.548 \\
\hline
\end{tabular}

From Table 7, diversity was highest at sites 1 (in the headwaters) and 5 (farther down the district). At site 1 , individuals were well distributed over the taxa (67.3\%, or $\mathrm{E}$ $=0.673$ ). This uniformity gradually decreased at sites 2,3 , and 4 with the increasing sewage discharge. At site 5, although the taxonomic richness was lowest, the uniformity increased again (dominance was low).

Taxa similarity at each site is described by the Jaccard index. From Figure 3, at sites 1 and 2, located upstream the district, similarity is approximately 0.28 . At the other sites, in and downstream the district, similarity values are different.

Figure 3 - Dendrogram based on Jaccard similarity indices for taxa of benthic macroinvertebrates collected in the studied stream

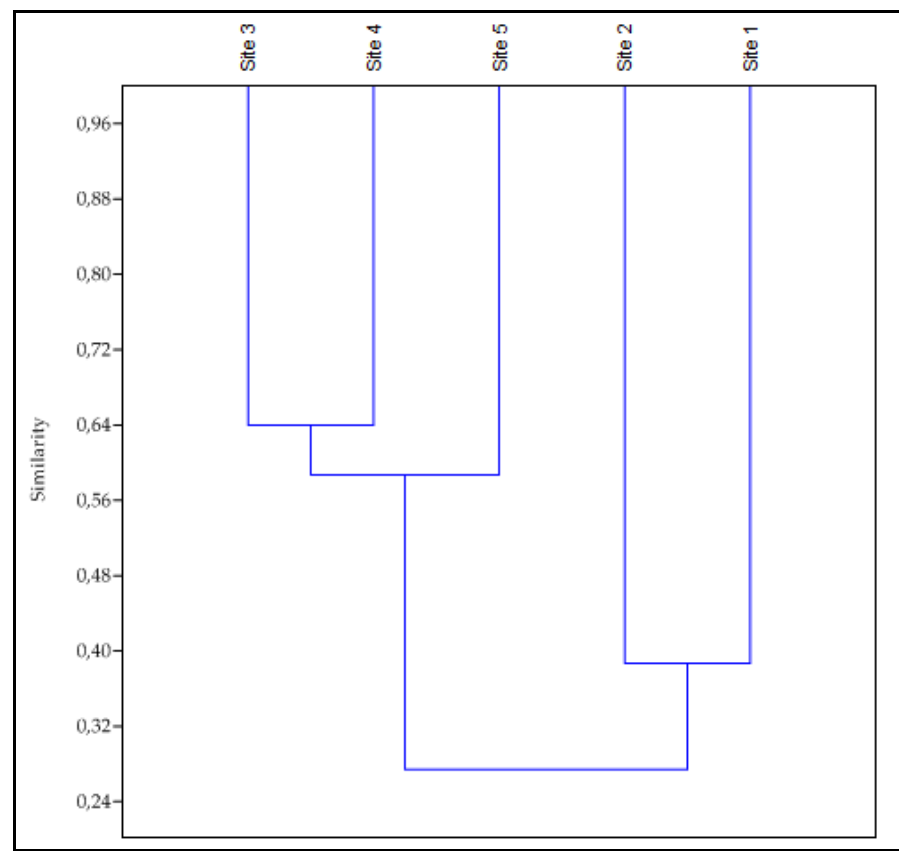




\section{Conclusion}

Pollution effects were verified by the analysis of physicochemical parameters and calculation of BMWP', diversity, and similarity indices.

BMWP' indices were highest at sites 1 and 2 (upstream the district) with water quality varying from acceptable (slightly polluted) to questionable. Dissolved oxygen were highest, and total phosphorus was lowest. A high diversity was observed, with the occurrence of pollutant-sensitive organisms. Taxa were more uniformly distributed. From the principal components analysis and by the Jaccard index, both sites were in a separate group, in comparison with the other sites.

Water at site 2 was ranked class 1 (excellent) by Resolution 357/05, but not as good by the biological indices. According to GOULART and CALISTO (2003), the sole utilization of physicochemical variables to assess impacts on aquatic ecosystems is subject to a temporal and spatial discontinuity in the collected data. Because of the unidirectional flow of lotic ecosystems and their capacity of self-purification, solid effluents that are carried into streams may be diluted, and their properties not detected in the collected samples. In addition, physicochemical monitoring is neither suited for detecting alterations in the diversity of habitats and microhabitats, nor sufficient to determine the consequences of these alterations on biological communities.

At sites 3, 4, and 5 dissolved oxygen was lowest and total phosphorus was highest. Water at these sites was considered polluted, by the BMWP' index, and poor, by Resolution 357/05. Diversity was lowest, except for site 5. Equivalences can be observed in (i) the Jaccard similarity dendrogram for all three sites; (ii) the occurrence of common taxa, with predominance of tolerant species; and (iii) the absence of pollution-sensitive species. Despite the comparatively high diversity rate at site 5 , it was found that pollutants are present and are being carried to the Passo Fundo River and, consequently, to the Carahá River.

We conclude that the investigated stream is, from source to canalization, completely contaminated and undergoing continued anthropogenic impact. It is an 
example of the majority of the urban bodies of water in Brazil. More research on water monitoring and remediation measures are needed. Also, sewage treatment systems should be implemented in these areas in order to improve water quality and consequently life quality of the affected populations.

\section{Acknowledgments}

We wish to thank the State Experimental Station for Agricultural and Livestock Research (EPAGRI) and Dr. Tássio Dresch Rech for the technical support in the development of this research.

\section{References}

ALBA-TERCEDOR, J., SÁNCHEZ-ORTEGA, A. (1988). Un método rápido y simple para evaluar la calidade biológica de las águas corrientes basado em el de Hellawell (1978). Limnética, v. 4, p. 51-56.

BARBOLA, I.F., MORAES, M.G., ANAZAWA, T.M., NASCIMENTO, E.A., SEPKA, E.R., POLEGATTO, C.M., MILLÉO, J., SCHÜHLI, G.S. (2011). Avaliação da comunidade de macroinvertebrados aquáticos como ferramenta para o monitoramento de um reservatório na bacia do Rio Pitangui, Paraná, Brasil. Iberingia, Série Zoologia, Porto Alegre, n. 101, p. $15-23$.

BISPO, P.C., OLIVEIRA, L.G., BINI, L.M., SOUSA, K.G. (2006). Ephemeroptera, Plecoptera and Trichoptera assemblages from riffles in mountain streams of Central Brazil: environmental factors influencing the distribution and abundance. Revista Brasileira de Zoologia, n. 66, p. 611-622.

BRASIL. Política Nacional de Recursos Hídricos. Lei no 9.433 de 8 de janeiro de 1997. Presidente da república, Brasília, DF, 1997.

BRASIL. Resolução CONAMA n 357 de 17 de março de 2005. Conselho Nacional do Meio Ambiente: CONAMA, Brasília, DF, março de 2005.

BUSS, D.S., BAPTISTA, D.F., NESSIMIAN, J.L. (2003). Bases conceituais para a aplicação de biomonitoramento em programas de avaliação da qualidade da água de rios. Cadernos de Saúde Pública. Rio de Janeiro, v. 19, n. 2, p. 465-473. 
COPATTI, C.E., SCHIRMER, F.G., MACHADO, J.V.V. (2010). Diversidade de Macroinvertebrados Bentônicos na Avaliação da Qualidade Ambiental de uma Microbacia no Sul do Brasil. Perspectiva, Erechim, v. 34, n. 125, p.79 - 91.

CUNHA, A.C., CUNHA FERREIRA, A.H., ARAÚJO, J.S., SILVA, A.N., PANTOJA, S. (2005). Monitoramento de águas de superfície em Rios estuarinos do estado do Amapá sob poluição microbiológica. Ciências Naturais, Belém, v. 1, n., p. 191-199.

FERREIRO, N.R.B. (2007). Caracterização da qualidade ecológica do rio Tua. Dissertação (Mestrado em Hidrobiologia Departamento de Zoologia e Antropologia) Faculdade de Ciências da Universidade do Porto, Porto.

GONÇALVES, F.B. (2007). Análise comparativa de índices bióticos de avaliação de qualidade de água, utilizando macroinvertebrados, em um rio litorâneo do estado do paraná. Dissertação (Mestrado em Ecologia e Conservação) - Universidade Federal do Paraná - Curitiba.

GOOGLE EARTH Pro. 2017. Version 7.3.0.3832. Access: 24 dez. 2017. Nota (Lages, SC).

GOULART, M., CALLISTO, M. (2003). Bioindicadores de qualidade de água como ferramenta em estudos de impacto ambiental. Revista da FAPAM, ano 2, no 1. 9p.

IBGE - Instituto Brasileiro de Geografia e Estatística. Pesquisa Nacional de Saneamento Básico 2008. Rio de Janeiro: IBGE, 2008. From: http://www.ibge.gov.br/home/presidencia/noticias/imprensa/ppts/0000000105.pdf. Access: 11 mar. 2017.

KONIG, R., SUZIN, C.R.H., RESTELLO, R.M., HEPP, L.U. (2008). Qualidade das águas de riachos da região norte do Rio Grande do Sul através de variáveis físicas, químicas e biológicas. Pan-American, Journal of Aquatic Sciences, v.3, n. 1, p. 84-93.

LOYOLA, R.G.N. (2000). Atual estágio do IAP no uso de índices biológicos de qualidade. In: Anais do V Simpósio de Ecossistemas Brasileiros: Conservação. ACIESP, São Paulo, pp. 46-52.

MERRIT, R.W., CUMMINS, K.W., CAMPBEL, E.Y. (2014). Uma Abordagem Funcional Para a Caracterização de Riachos Brasileiros, p. 69-88. In: Hamada,N; Nessimian, J.L.; Querino, R.B. (eds). Insetos aquaticos na Amazonia brasileira: taxonomia, biologia e ecologia. Manaus: Editora do INPA, 724p.

MOZETO, A.A., UMBUZEIRO, G. A., JARDIM, W. F. (2006). Métodos de coleta, análises físico-químicas e ensaios biológicos e toxicológicos de sedimento de água doce. São Carlos: Cubo multimídia, 224 p.

ORTIZ, N., GODÓI, E.L., POLAKIEWICZ, L., PIRES, M.A.F. (2008). Monitoramento de águas de superfície densamente poluídas- o córrego Pirajuçara - localizado na região Metropolitana de São Paulo. R. Exacta, v. 6, n. 2, p. 245-257. 
RORIG, L.R. (2013). Algal Analysis. In. NOLLET, L.M.L; GELDER, L.S.P. (Ed). Handbook of Water Analysis. 3 ed, CRC Press, 979 p.

ROSENBERG, D.M., RESH, V.H. (1993). Fresh water biomonitoring and benthic macroinvertebrates. Chapman\&Hall, Lodres, $486 \mathrm{p}$.

Secretaria Do Meio Ambiente E Recursos Hídricos. Avaliação da Qualidade da Água Através dos Macroinvertebrados Bentônicos Índice BMWP. Governo do estado do Paraná, 2016. From: http://www.meioambiente.pr.gov.br/modules/conteudo/print.php?conteudo=91 Access: 10 mar. 2017.

SILVEIRA, M.P. (2004). Aplicação do biomonitoramento para avaliação da qualidade da água em rios. Jáguariúna: Embrapa Meio Ambiente, f. 68.

SILVEIRA, M.P., QUEIROZ, J.F., BOEIRA, R.C. (2000). Protocolo de coleta e preparação de amostras de macroinvertebrados bentônicos em riachos. Jáguariúna: Embrapa Meio Ambiente, f. 7.

ZANZINI, A.C.S. (2005). Descritores Quantitativos de Riqueza e Diversidade de Espécies. Lavras: UFLA/FAEPE, 43p. 